\title{
Tıp Fakülteme Mektubum Var!
}

\section{Have a Letter to My Medical School!}

\author{
Ayşen Melek AYTUĞ KOŞAN* (ORCID: 0000-0001-5298-2032) \\ Canan AKMAN* (ORCID: 0000-0002-3427-5649) \\ Çetin TORAMAN* (ORCID: 0000-0001-5319-0731) \\ *Çanakkale Onsekiz Mart Üniversitesi Tıp Fakültesi Çanakkale, TÜRKIYE \\ Sorumlu Yazar: Ayşen Melek AYTUĞ KOŞAN, E-Posta: aysenay1@yahoo.com
}

\section{Özet}

Amaç: Bu araştırmanın amacı Çanakkale Onsekiz Mart Üniversitesi Tıp Fakültesi (ÇOMÜTF) 2018, 2019 ve 2020 mezunu hekimlerin fakültelerine yönelik duygu, düşünce ve anlamlandırmalarını ortaya çıkarmaktır.

Yöntem: $\mathrm{Bu}$ araştırma, fenomonolojik nitel araştırma şeklinde tasarlanmıştır. Araştırmada uygun örnekleme yöntemi kullanılmıştır. Araştırmanın verileri ÇOMÜTF mezunu 32 pratisyen hekimden elde edilmiştir.

Araştırmada veriler mezunların fakültelerine yazdıkları mektuplardan elde edilmiştir. Nitel araştırma olarak tasarlanan bu araştırmada geçerlik ve güvenirlik adına gönüllü katılım, yapılan analizlerin araştırma dışı uzmanlara denetletilmesi yoluyla dış denetim, katılımcı doğrulaması, katılıcıların söylemlerinden doğrudan alıntı yapma stratejilerinden yararlanılmıştır. Verilerin analizi içerik analizi ile gerçekleştirilmiştir.

\author{
Anahtar sözcükler: \\ Tıp Eğitimi, Tıp \\ Fakültesi Mezunu, \\ Fenomonolojik \\ Araştırma \\ Keywords: \\ Medical Education, \\ Faculty of Medicine \\ Graduate, \\ Phenomenological \\ Research \\ Gönderilme Tarihi \\ Submitted: 01.04.2021 \\ Kabul Tarihi \\ Accepted: 17.05.2021
}

Bulgular: Mezun pratisyen hekimlerin mektupları kodlanmış, kodlardan kategorilere ve temaya ulaşılmıştır. Araştırmada tek tema elde edilmiştir: Fakültem. Fakültem teması altında, duygularım, eğitimim, hocalarım, öğrenciler ve mezunlar ne yapmalı, tıp eğitimi nasıl olmalı, çevremdeki insanların ÇOMÜTF hakkındaki düşünceleri kategorileri oluşmuştur. Bu kategoriler altında oluşan kodlar görselleştirilmiş ve katılımcılardan doğrudan aktarım yapılarak sunulmuştur.

Sonuç: Fakülteye yönelik kendine güvenme isteği, korku, kayg1, yetersizlik duygusu, fakülteye aidiyet eksikliği, mesleğine yabancılaşma, tıp eğitimi hakkındaki hayal kırıklıkları, bilgi ve beceri eksiliği hissi, yeterlilik hissi, fakültenin verdiği iyi eğitimden memnuniyet duyguları öne çıkmıştır. Bilgi eksikliği, hastaya yaklaşım eğitiminin yetersizliği, yeterli beceri edinememiş olmak, eğitimin teorik ağırlıklı olması, temel bilim klinik bilimler bağlantı eksikliği, eğitim ile günlük yaşam arasındaki uyumsuzluk, Türkiye'deki tüm tıp fakültelerinde eğitimin sorunu olduğu, bazı stajlar yararlıyken yararsız birçok stajın da olduğu ve bunların kaldırılması gerektiği, fakültenin öğrencilerine yeterli eğitim verdiği ve deneyim kazandırdığ düşünceleri öne çıkmıştır. Mezunlar halen öğrenim görmekte olan öğrenci arkadaşlarına seslenerek; kendini yetiştirmek isteyen hasta sorumluluğu almaya çalışır, uzmanlık eğitimine yönelmek gerekir, 
öğrenilenlerin pratiğe dönüştürülmesi gerekir, kendi kendine öğrenme becerisi edinmek gerekir, motivasyonu yüksek tutmak gerekir, öğrencinin bilgi ve becerilerini arttırmaya çalışan hocaların peşini bırakmamak gerekir, eksiklerinizi siz tamamlamalısınız, hastaya zarar vermemek önceliğimiz olmalı şeklinde önerilerde bulunmuşlardır. Mesleksel (klinik) becerilerin eğitimde önemsenmesi, hekimlerin bir ekibin üyesi olacak biçimde yetiştirilmesi, alacağı yetki ve sorumluluklar konusunda hekimlerin daha yetkin olacak şekilde yetiştirilmeleri, mesleksel egoların aşılması, mesleğe gereken özverinin yansıtılması, eğitimde olgu sunumlarının önemsenmesi, klinik dönemin tamamıla uygulama olması, mezun deneyimlerinden halihazırda öğrenim gören öğrencilerin yararlanmalarının sağlanması, iletişim ve sosyal beceriler konusunda daha iyi yetiştirilmeleri gerektiği mezunların önerileri arasında yer almıştır.

\section{Abstract}

Aim: This study aims to examine the feelings, views and interpretations of the graduate students (2018, 2019 and 2020) of Çanakkale Onsekiz Mart University Faculty of Medicine (COMUFM) towards their faculties.

Methods: This study was based on the principles of phenomenological qualitative research design. Convenient sampling method was used in the study. The data were obtained from 32 medical faculty graduates who are general practitioners. The data in the study were collected through letters written by the graduates to the faculties they graduated. To ensure the validity and reliability of this study, which was designed as a qualitative research, several strategies such as voluntary participation, external auditing, participant verification, and direct quotation from participants' statements (verbatim examples) were used. The data were analyzed using content analysis.

Results: The letters written by the graduates were coded, and the theme and categories were obtained from these codes. Only one theme was obtained in the study: My faculty. Under this theme, the categories are (1) my feelings, (2) my education, (3) faculty members, (4) what do students and graduates have to do, (5) how should medical education be, and (6) what others think about COMUFM. The codes created under these categories were visualized and presented through verbatim examples from the participants. Conclusions: The most prominent feelings obtained were self-confidence towards the faculty, fear, anxiety, inadequacy, lack in the sense of belonging to the faculty, professional alienation, disappointment about medical education, lack of knowledge and skills, feeling of competence, being satisfied with the education provided by the faculty members. The most common views obtained were lack of knowledge, the inadequacy of education for the approaches to patient, being unable to obtain required skills, theoretical training more than practical training, the lack of connection between basic science and clinical science, the mismatch between education and real life, the education of all medical faculties in Turkey is problematic, some of the internships should be removed, and the faculty members provide quality education and opportunity to experience for their students. The graduates addressed the fellow students by suggesting "the ones who would like to train themselves try to take the responsibility of the patient", "we need focus on residency training", "we need to put what we have learned into practice", "we need to learn effective self-learning strategies", "motivation should be kept high", " we should be hard on the faculty member's heels who have always aimed to increase students' knowledge and skills", "You must correct your deficiencies", "not to harm the patient should be our priority". The graduates suggested that the medical students should care about the clinical skills, the physicians should be trained to work in a team, they should be trained more effectively in terms of the authorities and responsibilities they will take, overcome the ego related to your profession, work selflessly, should take case reports seriously in the training, clinical training should be fully hands-on, it should be ensured that students benefit from the experience of graduates, medical students should be better trained in terms of communication and social skills. 


\section{GíRiş}

Hekimlik, Türkiye'de popüler olan, mezun olduğunda mesleğe ataması kolay ve ekonomik bağımsızlığın kazanılabileceği, toplumda statüsü iyi olan meslek gruplarından biridir. $\mathrm{Bu}$ yönüyle tıp fakülteleri de halihazırda üniversitelere giriş sınavlarından en yüksek puan alan öğrencilerin tercih ettiğ fakülteler arasında yer almaktadır. İnsan hayatını, sağlığı temele alan hekimlik mesleği zor, kapsaml, yoğun bilgi ve kompleks becerilerin kazandırılması temelinde bir eğitim yapısına sahiptir. Patterson, Ferguson ve Knight [1] tip eğitiminde öğrencilerin, yüksek akademik bilgiye ek olarak bir dizi başka önemli beceri ve niteliklere sahip olmasının hayati önem taşıdığını belirtmiş̧tir. Lisede yıllarca süren titiz çalışmalardan sonra tıp fakültesine girmenin ve tıp öğrencisi olmanın her zaman zor olmasının nedeni bu olabilir. Çünkü öğrencilerin belirtilen yeterlikleri kazanmasını temel alan ve kapsamlı değerlendirme sürecini içeren yoğun bir eğitim programına dahil olmaları gerekecektir [2]. Tip öğrencileri nasıl araştırma yapacaklarını [3], nasıl eleştirel düşüneceklerini [4] ve gerçek hayattaki problemleri nasıl çözeceklerini $[5,6]$ kısaca nasil ve hangi yollardan öğrenebileceklerini öğrenen bireyler olarak yetişmelidir. Hekimlik daha üniversiteden mezun olmadan önce toplum tarafindan sayg1 duyulan ve güvenilen bir meslektir $[7,8,9]$.

Edinburgh bildirgesi tıp eğitiminin temel amacını ortaya koymuştur; "tüm insanların sağlık düzeylerini yükseltecek hekimler yetiştirmek" $[10,11]$. Türkiye'de tıp eğitimi ile ilgili bazı sorunlar dile getirilmiştir. Örneğin, toplumdaki yaygın sağlık sorunlarının yeterince öğretilmediği, buna karşın daha nadir rastlanan hastalıkların gereksiz biçimde ayrıntılı olarak ögretildiği [12, 13], tıp fakültelerinin fiziki ve alt yapı sorunları olduğu ve buna bağlı olarak uygulamaların yetersiz yapılması ya da hiç yapılmaması, özgüven eksikliği yaşayan hekim yetiştirildiği, belki de en büyük görevi koruyucu hekimlik uygulamaları olacak pratisyen hekimlerin bu konuda yetersiz bilgi ile mezun edildiği, hekimlerin uzmanlık eğitimine yönlendirildiği $[14,15]$, gereğinden fazla teorik bilgi ile yüklenen hekimlerin toplumun sağlık ihtiyaçlarına yanıt verememesi [16] bunlardan birkaçıdır.

T1p fakültesi öğrencileri çoğunlukla fakülte ya da üniversiteye (rektörlük) bağlı sağlık uygulama ve araştırma hastanelerinde klinik uygulamalarını gerçekleştirmektedir. Üniversite hastaneleri, sağlık hizmeti sunumunda üçüncü basamak sağlık kurumlardır. Üçüncü basamağa başvuruda bulunan hastalar, birinci ve ikinci basamakta çözülemeyecek, daha karmaşık, bazen nadir hastalıkları olan, uzmanlık gereken ve uzmanlık alanlarına göre ayrışmış (koruyucu hekimlik bakış açısından çıkmış) hastalardır. Dolayısıyla üçüncü basamak hastaları daha çok kronik hastalardır. Oysa pratisyen hekimlerin büyük çoğunluğu aile sağlığı merkezleri (ASM), devlet hastanelerinin acil servisleri, ambulans doktoru vb. görevlerde yer alacak ve öncelikleri toplum temelli önleyici hekimlik düzeyinde olacaktır. Eğitimlerinin büyük kısmını üçüncü basamak üniversite hastanelerinde gerçekleştiren hekim adayları toplumdan, toplumun sağlık sorunlarından ve gelecekte çalışacakları sağlık sisteminden uzakta yetişmektedirler. Tıbbi uygulamalarla ilgili kaygı duyulması, tıp öğrencilerinin pratisyen hekim olarak kendilerine güvenmemesine ve uzmanlık eğitimini almaya yönlenmelerine neden olabilir [15]. Türk Tabipler Birliği (TBB) de bu soruna dikkat çekmiş, Mezuniyet Öncesi Tıp Eğitimi raporunda çözüm olarak Türkiye'nin gereksinimlerine uygun pratisyen hekim yetiştirilmesi, tıp eğitiminin topluma dayalı olarak ve problem çözmeye yönelik aktif eğitim yöntemi ile verilmesi önerilmiştir [17]. Uzun ve zorlu bir eğitimden geçerek hekim olan mezunlar, fakülteleri ve eğitimleri hakkında ne düşünmektedir? Şu anda mesleklerini icra eden ve hastaların sorumluluğunu üstlenen pratisyen hekimler aldıkları eğitimle üstlendikleri bu sorumluluğun üstesinden gelebiliyorlar $\mathrm{m}$ ? Fakülteleri ve aldıkları eğitim onları bu 
yetkinlik düzeyine çıkarabildi mi? Aldıkları eğitimin daha farklı olmasını isterler miydi? Mezunların fakülteleri, aldıkları eğitim üzerinde duygu ve düşüncelerinin neler olduğunu ögrenmeye çalışan bu sorular araştırmanın da temel motivasyon kaynağını oluşturmuştur. Bu araştırmanın amacı Çanakkale Onsekiz Mart Üniversitesi Tıp Fakültesi (ÇOMÜTF) 2018, 2019 ve 2020 mezunu hekimlerin fakültelerine yönelik duygu, düşünce ve anlamlandırmalarını ortaya çıkarmaktır.

\section{GEREÇ VE YÖNTEM}

Bu araştırmada, ÇOMÜTF 2018, 2019 ve 2020 y1lı mezunlarının fakültelerine yönelik düşünceleri ve anlamlandırmaları araştırılmıştır. Katılımcılardan fakültelerine yönelik duygu ve düşüncelerini ifade edebilecekleri mektup yazmaları istenmiştir. Araştırmada katılımcıların deneyimlerine ve deneyimlerden çıkacak anlamlara odaklanıldığ 1 için fenomenolojik bir araştırmadır. Fenomenolojik araştırmalar yakın deneyimler yaşamış insanların bu yaşantılarını algılamaları ve anlamlandırmaları üzerine odaklanır ve ortak yanlar bulmaya odaklanır. Bu ortak yönler, deneyimlerin özü olarak adlandırılır [18].

\section{Araşttrma Grubu}

Araştırmada uygun örnekleme yöntemi kullanılmıştır [19, 20, 21]. Araştırma grubunda yer alacak mezunların belirlenmesinde araştırmaya katılımda gönüllülük dikkate alınmıştır. Mezunlara 2017-2018,2018-2019 ve 2019-2020 Eğitim Yıllarında ön hekim dönem temsilciliği yapan öğrenciler (şu anda mezun) aracılığı ile araştırmaya katılım davetiyesi gönderilerek araştırmanın amacı açıklanmış̧ır. Gönüllü olan 32 mezun araştırma grubunda yer almıştır. Mezunlardan 2'si 2018, 4'ü 2019 ve 26's1 2020 Eğitim Yıllarında mezun olmuştur. Mezunların 12'si erkek 20'si kadındır.

\section{Etik Kurul Onayı}

$\mathrm{Bu}$ araştırma Çanakkale Onsekiz Mart Üniversitesi Bilimsel Araştırmalar Etik
Kurulunun 25.02.2021 tarih 04/45 say1lı olur kararı ile yürütülmüsstür.

\section{Veri Toplama Aract}

Araştırma verileri katılımcıların fakültelerine yazdıkları mektuplar ile toplanmıştır. Katılımcılara yazacakları mektupta yer vermeleri gereken konu başlıkları ile ilgili bir yönlendirme yapılmamıştır. Bunun nedeni, mektup yazımında katılımcıların olabildiğince az kısıtlanması, anlatımlarını serbest şekilde yapabilmeleridir. Katılımcılara mektubun ne kadar uzunlukta olacağına dair bir telkinde bulunulmamıştır. Her katılımcıya mektubu istediği kadar uzun yazabilecekleri, kendilerini mektup yazmaya hazır hissettiklerinde yazmaları, mektubu kâğıt ya da dijital ortamda yazabilecekleri vurgulanmış, mektuplar üzerindenveriler Şubat-Mart 2021 döneminde toplanmıştır.

\section{Araştırmacıların Rolü}

Nitel araştırmalarda araştırmacıların yaklaşımları ve özellikleri önemlidir [22]. Araştırmacılardan biri tıp fakültesi mezunu, demografi, tıp eğitimi, ölçme ve değerlendirme alanlarında uzmanlaşmış bir hekim ve aynı zamanda öğretim üyesidir. Tip eğitimi anabilim dalında görev yapan araştırmacı tıp fakültelerinin hekim yetkinliklerine katkısının mezunlar gözünden değerlendirilmesi gerekliliği ilgi alanındadır. $\mathrm{Bu}$ nedenle araştırmada yer almak istemiş̧ir. Diğer bir araştırmacı tıp fakültesi mezunu, acil tıp alanında uzmanlaşmış bir hekim ve aynı zamanda öğretim üyesidir. Acil tıp stajının sorumluluğunu yıllardır büyük bir gönüllülükle yapmaktadır. Eğitim boyutuna verdiği önemle bu araştırma ilgi alanına girmektedir. Diğer bir araştırmacı psikolojik danışmanlık ve rehberlik, eğitimde ölçme ve değerlendirme, eğitim programları ve eğitim istatistiği alanlarında uzmanlaşmış doktora mezunu bir öğretim üyesidir. Üç yıldır tıp eğitimi anabilim dalında görev yapmaktadır. Eğitimle ilgili birçok konu 
ilgi alanına giren araştırmacı bu araştırmaya da büyük ilgi duyarak katılıışır.

Katılımcılar ile araştırmacılar veri toplama aşamasında bir arada bulunmamıştır. Katılımcılar kendilerini yazmaya hazır hissettikleri bir zamanda mektuplarını yazıp araştırmacılara iletmiştir. $\mathrm{Bu}$ nedenle veri toplama aşamasında bir etkileşim söz konusu olmamıştır. Ancak veri analizi sırasında araştırmacılar duygu ve düşüncelerinin farkında olarak önyargılarını paranteze alması (epoché) [22] gerektiğini bilerek veri analizini gerçekleştirmiştir. Araştırmacılardan ikisi hekim olduğu ve bu deneyimlerinin araştırmaya yaklaşımları konusunda önyargı oluşturabileceği gerçeğinden yola çıkarak içerik analizinde veri kodlaması boyutunda yer almamışlardır. Elde edilen verilerin kodlanması ve dış değerlendirmecilerin görüşüne açma kısımlarında eğitim bilimleri kökenli araştırmacı daha aktif rol almıştır.

\section{Geçerlik ve Güvenirlik Çalışmaları}

Nitel araştırma literatüründe kullanılan inanılırlık, nakledilebilirlik, güvenilirlik ve doğrulanabilirlik kavramları, nicel araştırmalardaki iç geçerlik, dış geçerlik, güvenirlik ve nesnellik kavramlarına karşılık gelmektedir [23]. Veri güvenirliği bakımından gönüllü katılım oldukça önemlidir [24]. Bu gerekçeyle katılımcılara araştırma hakkında detaylı açıklama yapılarak gönüllü katılım onamı alınmıştır. Güvenilir veri analizi adına her araştırmacının yaptığı kodlamaları diğer araştırmacıların denetimine sunması önerilir [22]. Araştırma verilerin analizinde yalnızca eğitim bilimci araştırmacı kodlamaları gerçekleştirmiş ve diş değerlendirici denetimine sunmuştur. Araştırmada dış değerlendirici olarak bu araştırmaya dahil olmamış, dışarıdan üç uzmanın elde edilen verileri ve bulguları denetlemesi, değerlendirmesi istenmiştir. Araştırmacılar tarafindan yapılan veri analizi bu uzmanların denetimine sunulmuştur. Bu yolla dış denetim [25, 26, 27] sağlanmıştır. İnandırıcılığın sağlanması için katılımcı doğrulaması stratejisinden yararlanılmıştır [26, 23]. Veriler çözümlendikçe ortaya çıkan tema, kategori ve kodlamalar, araştırmaya katılan 32 mezundan üçüne sunulmuş ve onların deneyimlerini yansıtıp yansıtmadığı konusunda onayları alınmıştır. Son olarak katılımcıların söylediklerine, birebir alıntılarla yer verilmiştir. Böylelikle doğrudan alıntı stratejisinden [25] yararlanılmıştır.

\section{Verilerin Analizi}

$\mathrm{Bu}$ araştırmada anlatıların analizinde içeriğe ve deneyimlerden ortaya çıan anlamlara odaklanılmıştır. İçerik analizinde araştırma süresince elde edilen nitel verilerinin işlenmesi, verilerin kodlanması, temaların bulunması, kodların ve temaların düzenlenmesi, bulguların tanımlanması ve yorumlanması [21] aşamaları bulunur. Kategorileştirmenin birçok yolu olduğunu dile getiren Mayring [28] iki çeşit kategorileştirmenin başat olduğunu dile getirmektedir: Tümevarımsal ve tümdengelimsel analiz. $\mathrm{Bu}$ araştırmada tümevarımsal içerik analizinden yararlanılmıştır. Tümevarımsal veri analizinde veri kodlanır, kodlardan kategorilere, üst kategorilere ve temalara ulaşılır. Bulgular kısmında doğrudan aktarımlar yapılarak araştırma bulguları detaylandırılmıştır. Metin içi doğrudan aktarımlarda her mezun M1, M2, M3 gibi kod ile gösterilmiştir.

\section{BULGULAR}

Mezunlar mektuplarını fakültelerine yazarken, fakültelerini insana benzetmiş ve bir insana mektup yazar gibi mektuplarını yazmışlardır. Dolayısıyla kodlar kategorilere ve her kategori de fakülteye ulaşır niteliktedir. Araştırmada tek bir tema oluşmuştur: "Fakültem". Mezunlar mektuplarında fakültelerine yaşadıkları duygularla, eğitimlerinden hatılladıklarıyla, hocalarının onlara sunduğu katkıyla seslendi. Diğer yandan mektuplarında şu anda öğrenci olsalar ve kendilerinin (mezunların) neler yapmaları gerektiğini söylediler. Tıp eğitiminin nasıl olması gerektiğine ve çevrelerindeki 
insanların ÇOMÜTF hakkındaki düşüncelerine yer vermeyi de ihmal etmedirler. Özetle bu araştırmada; 1) duygularım, 2) eğitimim, 3) hocalarım, 4) öğrenciler ve mezunlar ne yapmalı, 5) tıp eğitimi nasıl olmalıydı ve 6) çevremdeki insanların ÇOMÜTF hakkındaki düşünceleri kategorileri oluşmuştur.

\section{Duygularım}

Mezunların meslekte yaşadıklarıyla fakültelerinden ayrıldıktan sonra geçen zamanın Çanakkale'ye ve fakültelerine yönelik oluşturduğu özlem, onların fakültelerine yönelik duygu ifadelerinde yerini bulmuştur. $\mathrm{Bu}$ kategori altında ortaya çıkan kodlar Şekil 1'de gösterilmiştir.

Kendine güvenme isteği, korku, kayg1, yetersizlik duygusu, ÇOMÜTF'ye aidiyet eksikliği, mesleğine yabancılaşma, sadece üniversitenin bulunduğu şehre özlem, tıp eğitimi hakkındaki hayal kırıklıkları, bilgi ve beceri eksikliği hissi, yeterlilik hissi, ÇOMÜTF ile gurur duymama, yetersizliğin getirdiği güven azalması, fakültenin öğrenci geribildirimine verdiği önemden memnuniyet, ÇOMÜTF'nin verdiği iyi eğitimden memnuniyet, Çanakkale'ye özlem, mesleki olarak yaşanan zorluklar ama en önemlisi ve öne çıkanı da ÇOMÜTF'den duyumsanan gurur, mezunların yaşadığı duygular arasındadir.

Bir mezun fakültesinden yaşadığı durumu şu sözleriyle belirtmiştir:

M17: Atandiğım yerde ÇOMÜ'lü olmanın gururunu yaşıyorum. Gayet yeterli hissediyorum kendimi. Hatta iyi anlamda göze batıyoruz.

Bir mezun ÇOMÜTF'nin öğrencilerinin görüşlerine verdiği değeri, geribildirimlerin alınmasından duyduğu memnuniyeti şöyle belirtmiştir:

M5: Eğitimim sırasında çoğunlukla kendimi ÇOMÜ de eğitim almaya hak kazanmış biri olarak değil de işlerin yürümesini sağlayan çalışan olarak hissederdim. Güzel bir yönden de bahsetmek istiyorum. Diğer tıp fakültelerine oranla fakültemiz öğrencilerin geri dönüşlerine çok önem veriyor, değişime açık, internü köle gibi görmüyor, hakkımızı arayabiliyoruz. Diğer fakültelere oranla gerçekten ögrenci dostu. Teşekkür ederim bizi düşünen her hocamıza :)

Başka mezunlar kendisinin fakültesine sahip çıkmasının ve fakültesiyle gurur duymasının etrafindaki insanlara olan yansımasını şu sözleriyle anlatmaktadir:

M26: Gururla ve mutlu olarak paylaşıyorum ÇOMÜ tıp mezunu olduğumu. Çanakkale'de okumuş olmanın her türlü güzel yanını anlattığım için çevremden de genelde güzel dönütler alıyorum. Zaten sürekli olarak her olayda o gibi durumları Çanakkale'deyken nasil yaptığımızı anlatırken buluyorum kendimi. Hayatımın en güzel zamanlarını Çanakkale'de geçirdiğim için ve önemli deneyimleri Çanakkale'de edindiğim için çok mutluyum.

M29: Öncelikle okulumun adını, Çanakkale'mi her zaman gururla söylüyorum. ÇOMÜ tıp mezunu olmak, aslında büyük bir ailenin parçası olmak demek benim için. Adını her duyduğumda heyecanlanmak demek. Her zaman minnetle anmak demek. Evet yeni bir fakülte ve şu an gelişmekte olan bir fakülte ve bazl eksiklikleri de mevcut. Ama dişarıya yani diğer fakültelere ve mezun olan meslektaşlarıma baktı̆̆ımda benzer sorunların diğer fakültelerde de olduğunu fark ettim. ÇOMÜ'nün farkıysa gelişmek için çabalayan çok klymetli hocalarımıza sahip olmast.

\section{2. Ĕ̈itimim}

Mezunların mezuniyetleri ve göreve başlamaları, hizmet sunmaları ile aldıkları eğitim üzerinde düşünmüş oldukları anlaşılmaktadır. Çünkü mektuplardaki bazı ifadeler aldıkları eğitim üzerinde sorgulama 
sonuçları düzeyindedir. $\mathrm{Bu}$ kategori altında ortaya çıkan kodlar Şekil 2'de gösterilmiştir.

Travma ve yoğun bakım bilgi eksikliği, ambulans doktoru olarak çalışmada bilgi eksikliği, pratik eğitimlerin yetersizliği, hastaya yaklaşım eğitiminin yetersizliği, yeterli beceri edinememiş olmak, eğitimin teorik ağırlıklı olması, temel bilimlerde öğrenilenlerin klinikteki önemini anlayamama, eğitim ile günlük yaşam arasındaki uyumsuzluk, her hekim adayının eğitiminde bir an önce hasta ile iç içe olmasındaki eksiklik, ön hekimlik süresinde hastaların tam olarak sorumluluğunu alamamış olmak, fakültenin öğrencilerine ne olmamaları gerektiğini öğretmesi mezunların eğitimden yakınmaları olarak görünmektedir. Alınan eğitim sonucunda mezunların hissettiği yetersizliğin ÇOMÜTF'nin değil, diğer tüm fakültelerin sorunu olduğu, bazı stajların yararlıyken yararsız birçok stajın da olduğu ve bunların kaldırılması gerektiği, fakültenin öğrencilerine yeterli eğitim verdiği ve deneyim kazandırdığı, diğer fakültelerden mezun hekimlerin henüz reçete dahi yazamadıkları yönünde değerlendirmeler de yapılmıştır. ÇOMÜTF'nin verdiği eğitim düzenlenmesi gerektiğini belirten mezunlar olmuştur.

Bir mezun çalışma hayatında fakültedeyken yaşadıkları sorunların sadece ÇOMÜTF sorunu olmadığı, genel olarak tıp eğitiminde yaşanan sorunlar olduğunu şu sözleriyle belirtmiştir:

M12: Fakültedeyken hepimizin şikâyet ettiği şeyler vardl ve bunlar kendi okulumuzla alakal olarak görüp eleştirilerimizde sert olduğumuz zamanlar oluyordu. Mezun olduğumda fark ettiğim şeylerden biri de aslında herkesin böyle olduğu acı gerçeğiydi. Çanakkale Onsekiz Mart olarak aslında şanslı olduğumuzu okurken de biliyor olsam da tıp eğitiminin çoğu fakültede sıkıntılı olduğu gerçeğiyle yüzleşmek açıkçası beni üzdü.
Fakültede iyi eğitim aldığını düşünen bir mezunun sözleri şöyledir:

M8: Öncelikle okurken hissetmesek de çoğu fakültedeki ön hekimlikten daha kaliteli bir acil intörnlüğü yapıyoruz. Hayatında hiç üsye reçetesi bile yazmamış hekim arkadaşlarım vard göreve gittiğim yerde. Bu açıdan hızl bakı sistemi ÇOMÜ acil intörnlüğ̈̈nün en yararlı uygulamalarından. Çünkü çalıştı̆̆ınız yerde basit yeşil alan hastalarına bile müdahale edemiyor gibi gözükmek size duyulan güven ve saygl açısından oldukça olumsuz olur. Ancak bunun yanında tek başına nasıl hasta sevk edileceğini, sevk zincirinin, 112 komutasının nasıl işlediğini, gelen sevki kabul etme reddetme ile ilgili yaklaşımları, sorumlulukları ve haklarımızı bilmiyoruz. Fakülteden mezun olmadan bunlar öğrenmenin oldukça önemli olduğunu düşünüyorum. Fizyoloji dersinde gördüğümüz solunum hacim ve basınçlarının sadece teorik bilgi olarak unutulmasindansa klinik pratikteki yerinin önemini ögrrenciyken anlayamayabiliyoruz.

Bazı mezunlar da aldıkları eğitimde her stajdan aynı faydayı göremediklerini vurgulamıştır:

M13: Mezun olalı 1 yıla yakın bir süre oldu, bu sürede keşke şunu da ögretselermiş dediğim çok şey oldu. Maalesef fakültemizin pratisyenlik anlamında öğrettiklerinin yeterli olmadığını düşünüyorum. Bu konuda bize en çok yardımcı olan, hastayı ve uygulamalart bize bırakıp bize hekimlik özgüvenini aşılayan en iyi branş acil tıp. Yeterli hissetmediğim konulardan biri: çocuk hastalar. Periferde çocuk hasta sayımı çok fazla ve inanın ilk geldiğimizde basit bir üsyeye bile ne yazllyyordu diye düşündügüm çok oldu. 


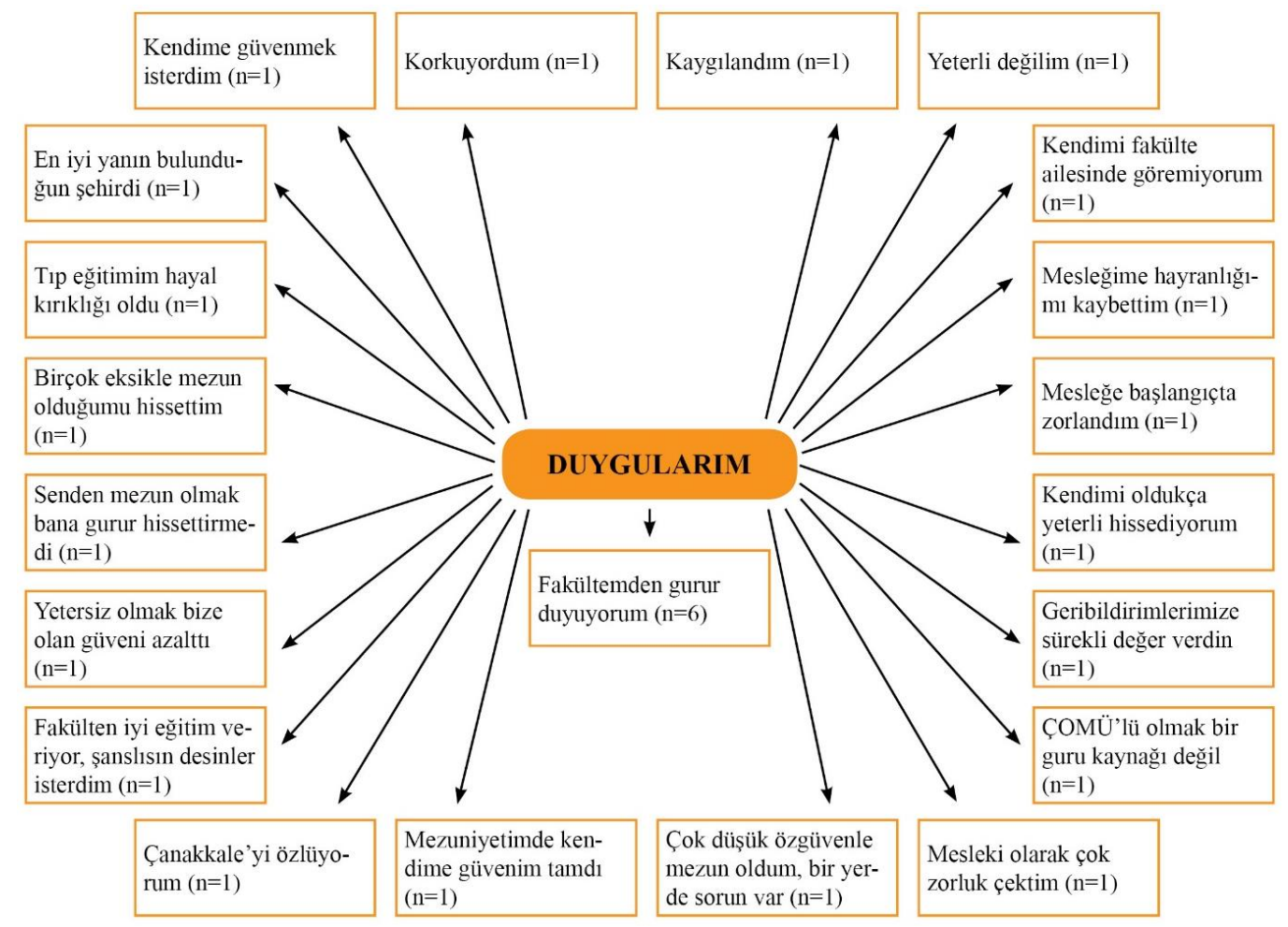

Şekil 1. Mezunların hissettiği duygular (kodların söylenme sıklığı merkezde yer alan kategoriye yakınlığı belirtir) 
Hekimlerin sadece hastanede çalışmadığ ambulans doktorluğuna da atanan pratisyen hekimler olduğunu belirten mezunlar, bu gibi eğitimlerin öğrencilik yıllarında eksik kaldığını düşünmektedir.

M9: Sudan çıkmış balı̆̆a döndüm, çünkü şu an çalıştı̆̆ım ambulans doktorluğu ya da komuta kontrol merkezi ile alakall herhangi bir eğitim almadik, bir ziyarette bile bulunmadik. Etrafimdaki başka üniversitelerden mezun olan doktorların çoğu bu kurumlara da gitmişler ve en azından işleyiş hakkında bilgi sahibi olmuşlar. Umarım intörn senesine eklenir ve hiçbir şey bilmeden atanmış olmaz meslektaşlarımız.

Ülkemizde tıp eğitiminin geldiği noktada yaşanan sorunlara da değinen mezunlar olmuştur.

M30: Açıkçası artık her gün mantar gibi türeyen yeni tıp fakülteleri varken köklü birkaç okuldan mezun değilseniz kimse nerden mezun olduğunuzla pek ilgilenmiyor. Bunun önümüzdeki yıllarda daha çok hissedileceğini düşünüyorum. Ayrica şişirilmiş kontenjanlar sayesinde mezun sayısı gitgide arttıkça buna bağlı düşecek olan kalite tüm mesleğin itibarını etkileyecek. Belki de zaten amacın bu olduğu gibi karamsar bir düşünceye kapılmamaya çalışıyorum.

\section{Hocalarım}

Mezunlar öğrencilik yıllarını hatırlayarak, eğitimlerinde önemli bir görev üstlenen öğretim üyelerine (hocalarına) dair düşüncelerini de paylaşmıştır. Bu kategori altında ortaya çıkan kodlar Şekil 3 'te gösterilmiştir.

Öğrencilerin bilgi ve becerilerini arttırma yolunda bazı öğretim üyelerinin gereksiz ayrıntıya girdiği belirtilmiştir. Mezunlar, öğrencilik yıllarında ÇOMÜTF'de etikten sıkça bahsettiği halde etik davranış sergilemeyen, öğrencilere mobbing uygulayan, öğrencileri küçümseyen, eğitime değer vermeyen bazı klinisyen eğiticiler, fakülteyi sadece yükselmek için bir basamak olarak gören, egosu çok yüksek, en çok da mesleğinin hakkını veremeyen bazı hocalarının da bulunduğunu ifade etmiştir. Hocaları hakkında daha olumlu düşünen, öğrenciye çok değer veren hocaların da olduğunu belirten mezunlar da olmuştur. Her ne kadar hekimlik rolleri olsa da hocalarının öğrencileriyle de ilgilenmesini isteyen bir mezun, referans mektubu lazım olduğunda yaşadığı zorluğu şu sözleriyle aktarmıştır:

M1: Örneğin ben 3.siniftayken yurtdışındaki tam 200 kliniğe mail attım gözlemci olarak yaz tatilinde gidebilmek için. Tüm masrafları kendim karşılayacaktım. Geri dönüş yapan klinik sayısı ve cevapları gerçekten içler acısıydl. Referans mektubu rica ettiğimde veren sadece tek bir hocam oldu. Bence destek olan hoca sayımızın 'orda ne işin var' diye soran hoca sayımızdan daha fazla olmasl gerekir.

Bazı hocaların yeterlik düzeylerini olumlu bulan bir mezun, bu hocaların peşinden koşmak gerektiğini önermektedir:

M3: ÇOMÜ ekolü olan bir okul değil. Hocalardan eğitim anlamında yetersiz olan da var, kendini yükseltmek amacıyla basamak olarak kullananlar da. Şansınız varsa yükselecek olan hocalarl yakalar, onlardan bir şeyler kapar ve mezun olursunuz.

Bir mezun hocalarının üniversitesine, fakültesine ve öğrencilerine daha çok sahip çıkması gerektiğini şu sözlerle anlatmıştır:

M10: Tiptan olmayan kişilerin yorumu Çanakkale çok güzel şehir şeklindeyken başka şehirlerde okumuş meslektaşlarımızın yaklaşımı genellikle “anladım” oluyor. Beni fakülte suresinde üzen başka bir şey var: Bazı hocalarımı gerek teorik derste gerek hasta başında bizlere hep "biz X üniversiteliler ne güzel ögrenirdik bunlarl, şunlardan biz sorumluyduk, hocalarımı söyle ögrretirdi, imkânlarımız söyle güzeldi, siz var ya aslında tıp okumuyorsunuz, sizinki 
kolay..." derdi. Oysaki o güzel gördükleri deneyimlerini bizim fakültemizde bizim eğitimimize katma şansları onların elindeydi.

\section{4. Ö̈̆grenciler ve Mezunlar Ne Yapmalı?}

Mezunlar şu anda fakültede öğrenci olan arkadaşları ve kendileri için de ödev çıkarmıştır. $\mathrm{Bu}$ ödevleri halen öğrenim gören arkadaşlarına ve kendilerine yönelik yazmışlardır. $\mathrm{Bu}$ kategori altında ortaya çıkan kodlar Şekil 4'te gösterilmiştir.

Fakültelerinin düzelmesini o kadar isteyen mezunlar vardır ki, kendilerinin akademisyen olması ve fakültelerine dönerek gereken düzeltmeleri yapması, ideal olanı kendilerinin yapması gerektiğini belirtmiştir. Halen öğrenim görmekte olan öğrenci arkadaşlarına seslenerek; kendini yetiştirmek isteyen hasta sorumluluğu almaya çalışır, uzmanlık eğitimine yönelmek gerekir, öğrenilenlerin pratiğe dönüştürülmesi gerekir, kendi kendine öğrenme becerisi edinmek gerekir, motivasyonu yüksek tutmak gerekir, öğrencinin bilgi ve becerilerini arttırmaya çalışan hocaların peşini bırakmamak gerekir, eksiklerinizi siz tamamlamalısınız, hastaya zarar vermemek önceliğimiz olmalı şeklinde önerilerde bulunmuşlardır. Diğer yandan tıp eğitiminin zor ve stresli bir süreç olmasından yola çıkarak, öğrenci arkadaşlarına hiç korkmayın sandığınızdan daha hazırsınız, öğrenciliğin tadını çıkarın biçiminde seslenen mezunlar da olmuştur.

Birkaç mezun, mesleğine sahip çıkmanın ve kendini geliştirmenin önemini şu sözlerle anlatmaktadir:

M21: Bu yolun sonu nereye çıkar nerede pes edip vazgeçeriz, bir gazete sayfasına ailemiz hüzünlü bir ilan mo verir tam o anda bir başka yol arkadaşın bilime ışık mı tutar bilmiyorum. Yaşadıklarımız, yaşayacaklarımı sadece bir ÇOMÜ'lünün dramı değil. Emin ol bir avuç yalnız değiliz. Bildiğim şey sen gibiler olmazsa dünya yaşanmaz olacak. Sesini çıkarmazsan, direnmezsen birileri haksızlı̆̆a uğrayacak ve sen bir hekim olarak ölümle yaşam arasındaki ince çizgide hep dans ediyor olacaksin. Emeğine, diline, aklına, bilime dayanan güçlerine, ailenden gelen güzel ahlaka, önünü aydınlatan ekol hocalarının emeklerine bir nebze bunlarl yazan bana, vicdanına ihanet etme. Yüzünde sicak gülümsemenle kal.

M24: Mezun olacak arkadaşlara tavsiyem şunlar; her firsatta EKG çektiğiniz hastanın EKG sini bilen biriyle birlikte değerlendirmeleri. Acil serviste daha efektif çalışmaları, kırmızı alan müdahalelerinde

entübasyon, defibrilasyon ilaç uygulamalarını bizzat kendilerinin uygulamast. Pediyatrik popülasyon için klinik becerilerini, muayene şekillerini, ilaç dozlarını uygulamalart, ellerinden geldiğince geliştirmeleri. Bol bol entübasyon, parasentez yapımına katılmaları, periferde işlerine çok yarayacaktır. Atanmadan önce tanilara göre kendilerine ait reçete örnekleri belirlemelerini de tavsiye ederim, acemilik döneminde onları çok rahatlatacaktır.

Bazı mezunlar da öğrencilik yaşamının ve tıp okumanın stresinden olsa gerek şu anda öğrenci olan arkadaşlarına şöyle seslenmiştir:

M18: Düzenli tekrar ve TUS'a yönelik çalışma. Fakülte derecesi istemiyorsanı kendinizi çok yormayın, bilgilerin hepsini unutacaksiniz. Dershaneyle tekrar hatırlayacaksınız. Hiç kasmaya gerek yok. Mental sağlığınız daha önemli.

M16: Kendilerini büyük ve köklü fakültelere göre yetersiz ve bilgisiz hissetmesinler. Mezun olduktan sonra etrafimızda gördüğ̈̈müz büyük fakültelerden mezun çoğu kişiyle aynı seviyede tıp bilgimiz olduğunu hatta çoğundan bu konuda ileride olduğumuzu fark ettim. 


\section{Tıp Ĕgitimi Nasıl Olmalı?}

Mezun olmak ve sonrasında kazanılan mesleki deneyimler "tıp eğitiminin nasıl olması gerektiği” üzerine de düşünmeye neden olmuş olsa gerek, mezunlar bu konuda da söylemlerde bulunmuştur. $\mathrm{Bu}$ kategori altında ortaya çıkan kodlar Şekil 5'te gösterilmiştir.

Mezunlar mesleki (klinik) beceriler eğitimde çok önemsenmesi, hekimlerin bir ekibin üyesi olacak biçimde yetiştirilmesi, alacağı yetki ve sorumluluklar konusunda hekimlerin daha etkin şekilde yetiştirilmeleri, mesleksel egoların aşılması, mesleğe gereken özverinin yansıtılması, eğitimde vaka sunumlarının önemsenmesi, klinik dönemin tamamıyla uygulama olması, mezun deneyimlerinden halihazırda öğrenim gören öğrencilerin yararlanmalarının sağlanması, iletişim ve sosyal beceriler konusunda daha iyi yetiştirilmeleri gerektiğini belirtmiştir.

Tıp eğitiminde hastaya müdahale ve hekimlik mesleğinin gereklerinin öğretilmesinin dışında, ekip üyesi olma ve iletişimin önemini kavramış bir mezun düşüncesini şöyle özetlemiştir:

M22: Kabul edelim ki tıp eğitimi içinde çok da dile gelmeyen ancak gerçekte son derece hissedilir bir hiyerarşi sistemi söz konusu. Öğrenciliğimizde bu sistemin en alt tabakasındayken mezun olduğumuzda bir anda sistemin en tepesine adeta ışınlanıyoruz. Herkesten emir alan bir pozisyondan bir anda tüm sorumluluğu üstlenen bir amir pozisyonuna geçiyoruz. Ben şahsen bu adaptasyonu yaşamakta zorlandım. Ben kendimi liderlik vasıfları konusunda başarll biri olarak tanımlamama rağmen bu bocalamam iş arkadaşlarım tarafindan hissedilecek olacak $k i$ aralarından beni yönlendirmeye çallşanlar oldu. Belki de bunların çoğu yaşayarak tecrübe edilecek şeylerdir ancak tıp ĕgitimimize bu öngörülerle eklenecek yeni programlar adaptasyon süreçlerinin daha yumuşak geçmesine katkı sağlar diye düşünüyorum.

\section{6. Çevredeki İnsanların ÇOMÜTF Hakkındaki Düşünceleri}

Mezunlar son kategoride çalıştıkları ortamlarda ya da etkileşime girdikleri çevrede bulunan insanların ÇOMÜTF hakkındaki düşüncelerini aktarmıştır. Bu kategori altında ortaya çıkan kodlar Şekil 6'da gösterilmiştir.

Bazı mezunlar kendilerinin ÇOMÜTF'yi fazlasıyla benimsediği için çevredeki insanların ÇOMÜTF hakkında olumlu konuştuğunu, sergiledikleri hekimlik becerilerini görenlerin ÇOMÜTF'nin kaliteli bir eğitim vermiş olabileceğini düşündüklerini belirtmiştir. Daha olumsuz düşünceler de belirtilmiştir. Örneğin, senin hakkında iyi düşünmüyorlar, eğitimini beğenmiyorlar, seni bilmiyor ve tanımıyorlar, fakülte olarak seni değil de bulunduğun şehri beğeniyorlar, eğitiminle insanların ilgisini çekmiyorsun gibi düşünceler belirtilmiştir.

Bir mezun çevresindeki insanların ÇOMÜTF hakkındaki düşüncelerini şöyle özetlemiştir:

M10: Tıptan olmayan kişilerin yorumu Çanakkale çok güzel şehir şeklindeyken başka şehirlerde okumuş meslektaşlarımızın yaklaşımı genellikle "anladim" oluyor. 


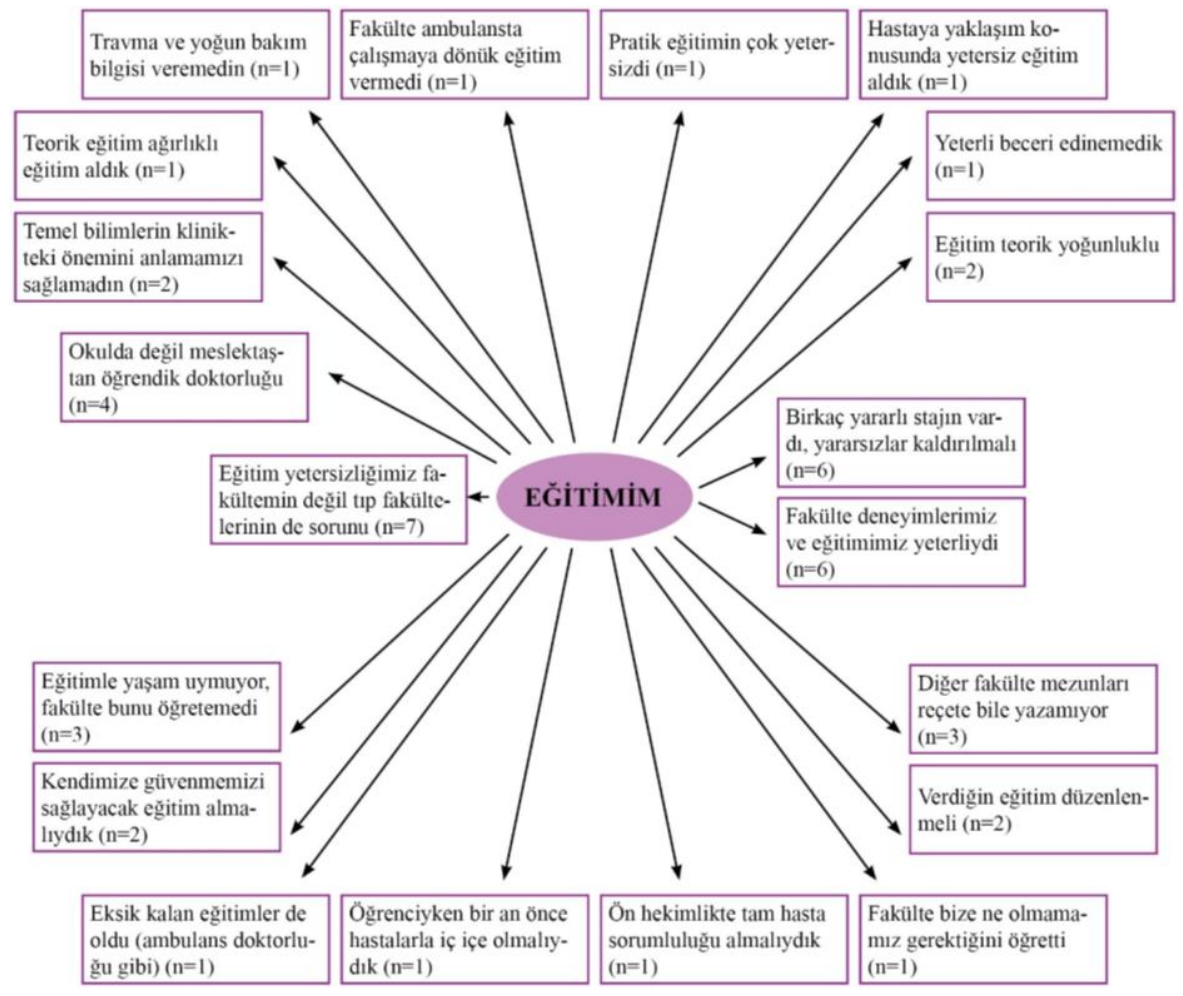

Şekil 2. Mezunların aldıkları eğitimle ilgili düşünceleri (kodların söylenme sıklığı merkezde yer alan kategoriye yakınlığı belirlemiştir) 


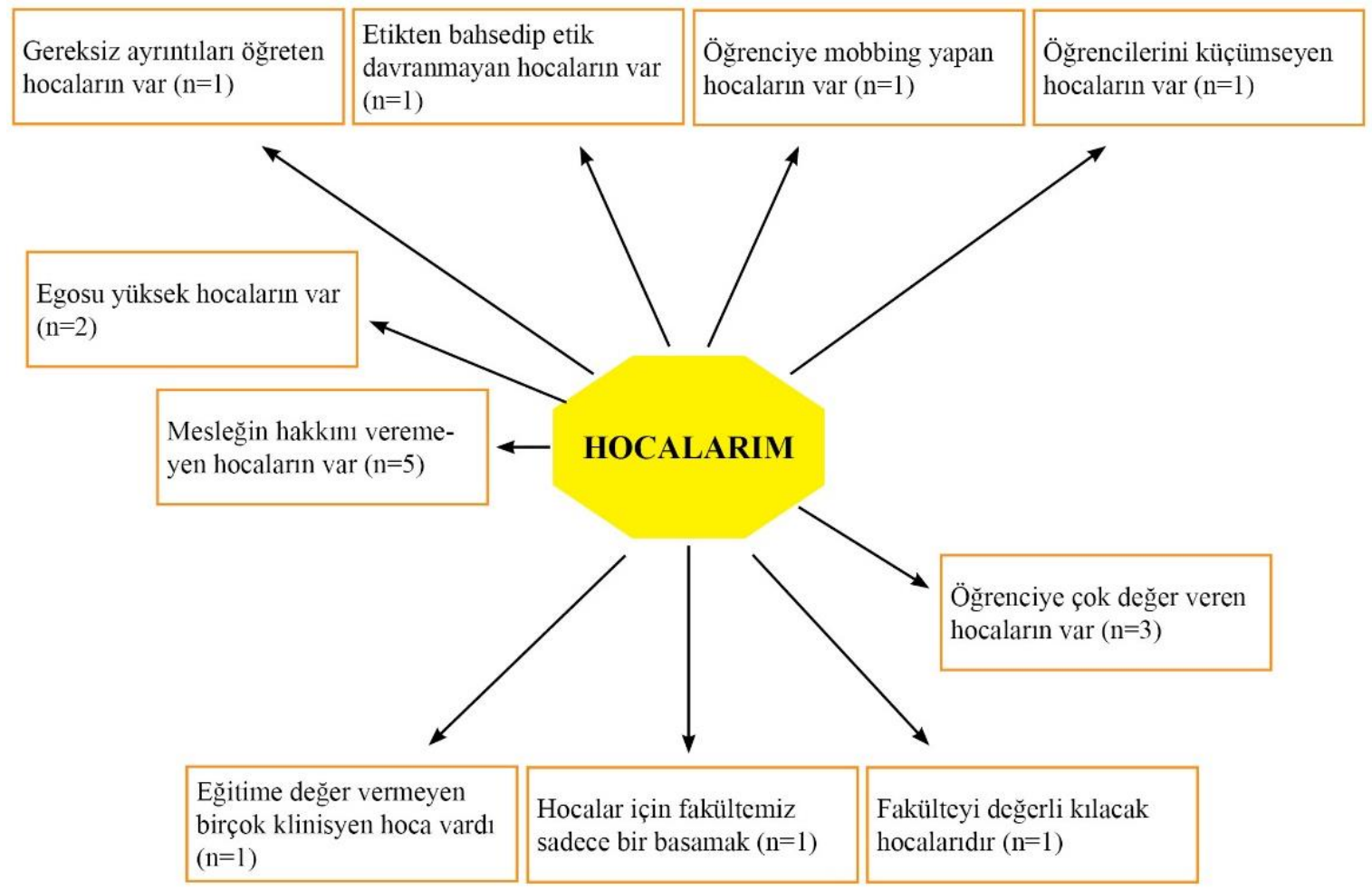

Şekil 3. Mezunların hocaları hakkındaki düşünceleri (kodların söylenme sıklığı merkezde yer alan kategoriye yakınlığı belirlemiştir) 


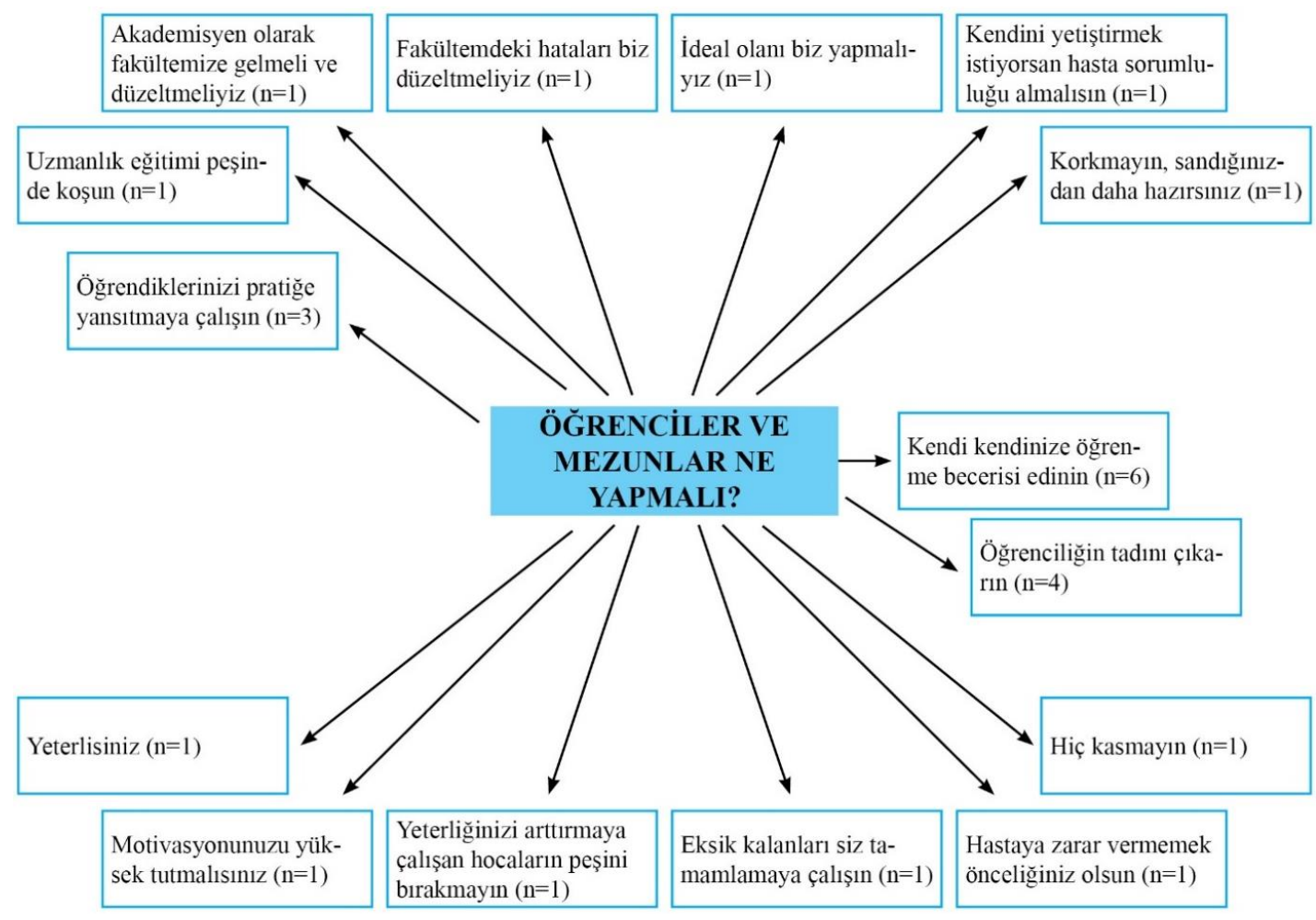

Şekil 4. Mezunlara göre şu anda öğrenim gören öğrenciler ve mezunların yapması gerekenler (kodların söylenme sıklı̆ğ merkezde yer alan kategoriye yakınlığı belirlemiştir) 


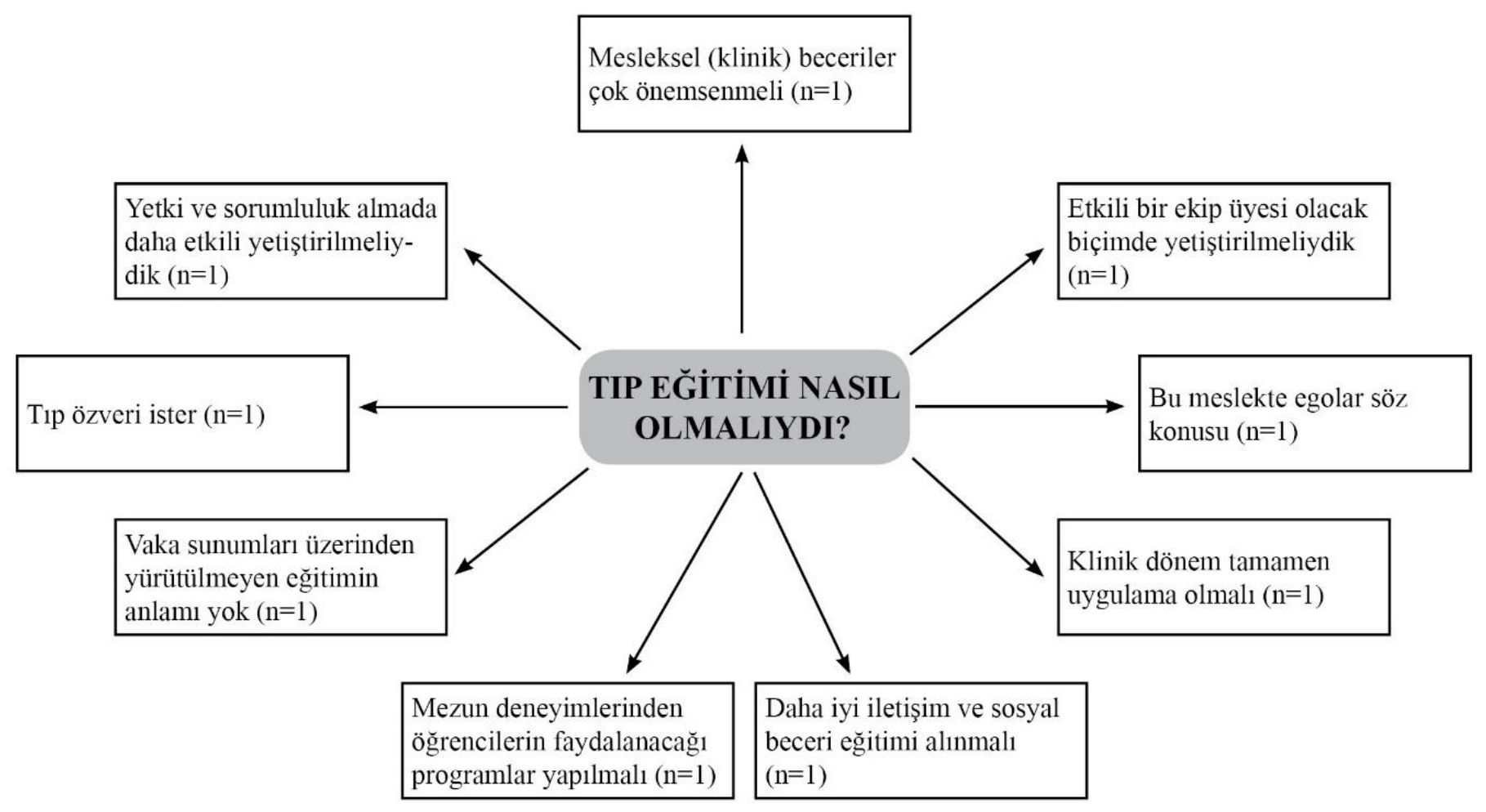

Şekil 5. Mezunlara göre tıp eğitimi nasıl olmalıydı (kodların söylenme sıklığı merkezde yer alan kategoriye yakınlığı belirlemiştir) 


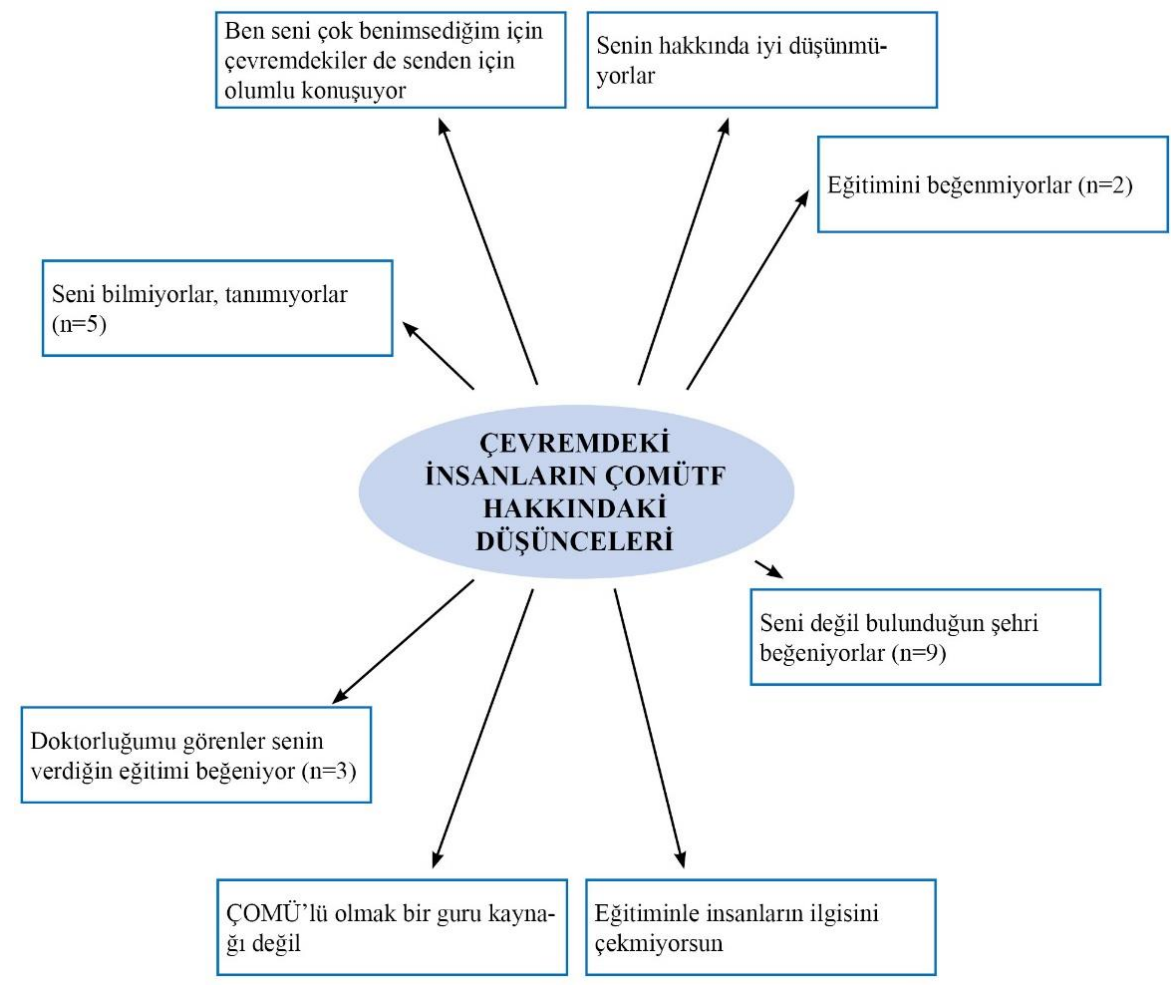

Şekil 6. Mezunlara göre çevrelerindeki insanların ÇOMÜTF hakkındaki görüşleri (kodların söylenme sıklı̆ğ merkezde yer alan kategoriye yakınlı̆̆ belirlemiştir) 


\section{TARTIŞMA}

Kendine güvenme isteği, korku, kaygı, yetersizlik duygusu, ÇOMÜTF'ye aidiyet eksikliği, mesleğine yabancılaşma, sadece üniversitenin bulunduğu şehre özlem, tıp eğitimi hakkındaki hayal kırıklıkları, bilgi ve beceri eksikliği hissi, yeterlilik hissi, ÇOMÜTF ile gurur duymama, yetersizliğin getirdiği güven azalması, fakültenin öğrenci geribildirimine verdiği önemden memnuniyet, ÇOMÜTF'nin verdiği iyi eğitimden memnuniyet, Çanakkale'ye, mesleki olarak yaşanan zorluklar ama en önemlisi ve öne çıkanı da ÇOMÜTF'den duyumsanan gurur mezunların yaşadığ $\breve{1}$ duygular arasındadır. Mezunların yeterlik, beceri, liderlik, bağlılık, güven duygu ve düşüncelerine yönelik bir araştırma da Özmen ve arkadaşları [29] tarafindan yapılmıştır. Araştırmada Gülhane Askeri Tip Akademisi (GATA) 2012 mezunlarının hekimlik yapmaya hazır hissetme durumu \%87,6 olmuştur. GATA mezunu olmaktan dolayı her zaman gurur duyacağını ve bunu her ortamda dile getireceğini ifade edenlerin oran $1 \% 85,5$, askeri hekimlere güven ve yakınlarını hastalıklarında onlara emanet etme oranı $\% 89,6$, eğitim için GATA tavsiye oran $1 \% 55,5$ 'tir. Morrison ve Moffat Glasgow [30] tıp öğrencilerinde stres oluşturan etkenlerin kişisel problemlerden daha çok aldıkları eğitime bağlı olabileceğini belirtmiştir.

Travma ve yoğun bakım bilgi eksikliği, ambulans doktoru olarak çalışmada bilgi eksikliği, pratik eğitimlerin yetersizliği, hastaya yaklaşım eğitiminin yetersizliği, yeterli beceri edinememiş olmak, eğitimin teorik ağıllıklı olması, temel bilimlerde öğrenilenlerin klinikteki önemini anlayamama, eğitim ile günlük yaşam arasındaki uyumsuzluk, her hekim adayının eğitiminde bir an önce hasta ile iç içe olmasındaki eksiklik, ön hekimlik süresinde hastaların tam olarak sorumluluğunu alamamış olmak, fakültenin öğrencilerine ne olmamaları gerektiğini öğretmesi mezunların eğitimden yakınmaları olarak görünmektedir. Alınan eğitim sonucunda mezunların hissettiği yetersizliğin ÇOMÜTF'nin değil, diğer tüm fakültelerin sorunu olduğu, bazı stajların yararlı olduğu, ancak yararsız birçok stajın da olduğu ve bunların kaldırılması gerektiği, fakültenin öğrencilerine yeterli eğitim verdiği ve deneyim kazandırdığı, diğer fakültelerden mezun hekimlerin henüz reçete dahi yazamadıkları yönünde değerlendirmeler de yapılmıştır. ÇOMÜTF'nin verdiği eğitimin düzenlenmesi gerektiğini belirten mezunlar olmuştur. Mezunların aldıkları eğitimi yetersiz bulmaları, eğitim programının iyi yapılandırılmadığını (öğrenim hedefleri, içerik vb.) düşünmeleri, kendilerini reçete yazma gibi konularda yetersiz hissetmeleri literatürün yabancı olmadığı, uzun zamandan bu yana dile getirilen ve üzerine öneri geliştirilen sorunsallar arasındadır. Whitfield tarafindan 1964'te gerçekleştirilen araştırmada mezunlar; yaşamda sık görülen hastalıklardan çok nadir görülen hastalıkların öğretilmesi, yetersiz bilgi ve beceri kazandırılmış olması, uygulama ve deneyim eksikliği, uzmanlık düzeyinde öğretilmesi gereken bazı konuların lisans düzeyinde (mezuniyet öncesi tıp eğitimi) öğretildiği, reçete yazmada dahi yetersizliklerini belirtmiştir [31]. Özmen ve arkadaşları [29] tarafindan yapılan araştırmada GATA 2012 tıp fakültesi mezunlarının fakültenin iyi hekim yetiştirme algıs1 $\% 81,3$ olumlu, toplum lideri hekim yetiştirme algısı $\% 62,5$ olumlu, iyi yönetici hekim yetiştirme algis1 \%60,5 olumlu olarak belirlenmiştir. Bu araştırma sonuçlarında da fakültenin eğitiminden memnun olan mezunlar olduğu gibi eğitimi çok yetersiz bulan mezunlar da vardır. Öğrencilerin bilgi ve becerilerini arttırma yolunda bazı ögretim üyeleri gereksiz ayrıntıya girmiştir. Mezunlara göre etikten sıkça bahsettiği halde etik davranış sergilemeyen, öğrencilere mobbing uygulayan, öğrencileri küçümseyen, eğitime değer vermeyen bazı klinisyen, fakültesi sadece yükselmek için bir basamak olarak gören, egosu çok yüksek en çok da mesleğinin hakkını veremeyen bazı hocalar vardı öğrencilik yıllarında ÇOMÜTF'de. Hocaları hakkında daha olumlu düşünen, 
öğrenciye çok değer veren hocaların da olduğunu belirten mezunlar olmuştur. Yarış, Topbaş ve Çan [32], Firth [33] tıp fakültesi ögrrencilerinin yaşadığı olumsuzluklar arasında eğitim aldıkları öğretim üyelerinin olumsuz tutumları olduğunu belirtmiştir. Mayda ve diğerleri [34] tarafindan gerçekleştirilen araştırmada tıp fakültesi öğrencilerinin öğretim üyeleri ve diğer personel olumsuz davranışlarından yakınma düzeyleri yüksektir. Öğrencilerin \%70,8'i öğretim üyelerinin olumsuz tutumlarından, \%76.7'si asistanların olumsuz tutumlarından şikayetçidir.

Fakültelerinin düzelmesini o kadar isteyen mezunlar vardır ki, kendilerinin akademisyen olması ve fakültelerine dönerek gereken düzeltmeleri yapması, ideal olanı kendilerinin yapması gerektiğini belirtmiştir. Halen öğrenim görmekte olan öğrenci arkadaşlarına seslenerek; kendini yetiştirmek isteyen hasta sorumluluğu almaya çalışır, uzmanlık eğitimine yönelmek gerekir, öğrenilenlerin pratiğe dönüştürülmesi gerekir, kendi kendine öğrenme becerisi edinmek gerekir, motivasyonu yüksek tutmak gerekir, öğrencinin bilgi ve becerilerini arttırmaya çalışan hocaların peşini bırakmamak gerekir, eksiklerinizi siz tamamlamalısınız, hastaya zarar vermemek önceliğimiz olmalı şeklinde önerilerde bulunmuşlardır. Diğer yandan tıp eğitiminin zor ve stresli bir süreç olmasından olsa gerek, öğrenci arkadaşlarına hiç korkmayın sandığınızdan daha hazırsınız, öğrenciliğin tadını çıkarın biçiminde seslenen mezunlar da olmuştur.

Mezunlar mesleksel (klinik) beceri eğitiminin de çok önemsenmesi, hekimlerin bir ekibin üyesi olacak biçimde yetiştirilmesi, alacağ 1 yetki ve sorumluluklar konusunda hekimlerin daha yetkin bir şekilde yetiştirilmeleri, mesleksel egoların aşılması, mesleğe gereken özverinin yansitılması, eğitimde vaka sunumlarının önemsenmesi, klinik dönemin tamamıyla uygulama olması, halen öğrenim gören öğrencilerin mezun deneyimlerinden yararlanmalarının sağlanması, iletişim ve sosyal beceriler konusunda daha iyi yetiştirilmeleri gerektiğini

vurgulamıştır.

Öğrencilerin eksikliklerini hissetmiş oldukları iletişim, ekip çalışması, liderlik gibi yeterlikler, ulusal ve uluslararası pek çok saygın kurum ve kuruluş tarafından tanımlanmış ve uluslararası düzeyde kabul görmüş tıp fakültelerinden mezun olan öğrencilerden beklenen asgari temel yeterlikler içinde yer almaktadır $[35,36,37,38]$. Özmen ve arkadaşları [29] tarafından yapılan araştırmada da GATA 2012 tıp fakültesi mezunlarının fakültelerinin iletişimi iyi olan hekim yetiştirme algısında $\% 12,5$ oranında olumsuz değerlendirmeye sahip olduğu belirlenmiştir.

Bazı mezunlar kendilerinin ÇOMÜTF'yi fazlasıyla benimsediği için çevredeki insanların ÇOMÜTF hakkında olumlu konuştuğunu, sergiledikleri hekimlik becerilerini görenlerin ÇOMÜTF'nin kaliteli bir eğitim vermiş olabileceğini düşündüklerini belirtmiştir. Ancak senin hakkında iyi düşünmüyorlar, eğitimini beğenmiyorlar, seni bilmiyor ve tanımıyorlar, fakülte olarak seni değil de bulunduğun şehri beğeniyorlar, eğitiminle insanların ilgisini çekmiyorsun gibi daha olumsuz düşünceler de belirtilmiştir.

\section{SONUÇ}

Çalışmaya katılan mezunların yazdıkları mektuplarda aldıkları eğitim ve fakültelerine yönelik yapmış oldukları eleştirileri/değerlendirmelerin çoğunun açık, yol gösterici ve üzerinde düşünülmüş olduğu görünmekte ve bununla birlikte tıp eğitimiyle ilgilenen, bu eğitimden sorumlu olanlara değerli veriler sağlamıştır. Fakülteye yönelik kendine güvenme isteği, korku, kaygı, yetersizlik duygusu, fakülteye aidiyet eksikliği, mesleğine yabancılaşma, tıp eğitimi hakkındaki hayal kırıklıkları, bilgi ve beceri eksiliği hissi, yeterlilik hissi, fakültenin verdiği iyi eğitimden memnuniyet duyguları öne çıkmıştır. Bilgi eksikliği, hastaya yaklaşım eğitiminin yetersizliği, yeterli beceri edinememiş olmak, eğitimin teorik ağırlıklı olması, temel bilim klinik bilimler bağlantı eksikliği, eğitim ile 
günlük yaşam arasındaki uyumsuzluk, Türkiye'deki tüm tıp fakültelerinde eğitimin sorunu olduğu, bazı stajların yararlı olduğu, ancak yararsız birçok stajın da olduğu ve bunların kaldırılması gerektiği, fakültenin öğrencilerine yeterli eğitim verdiği ve deneyim kazandırdığı düşünceleri öne çıkmıştır. Mezunlar halen öğrenim görmekte olan öğrenci arkadaşlarına seslenerek; kendini yetiştirmek isteyen hasta sorumluluğu almaya çalışır, uzmanlık eğitimine yönelmek gerekir, öğrenilenlerin pratiğe dönüştürülmesi gerekir, kendi kendine öğrenme becerisi edinmek gerekir, motivasyonu yüksek tutmak gerekir, öğrencinin bilgi ve becerilerini arttırmaya çalışan hocaların peşini bırakmamak gerekir, eksiklerinizi siz tamamlamalısınız, hastaya zarar vermemek önceliğimiz olmalı şeklinde önerilerde bulunmuşlardır. Mesleksel (klinik) becerilerin eğitimde önemsenmesi, hekimlerin bir ekibin üyesi olacak biçimde yetiştirilmesi, alacağı yetki ve sorumluluklar konusunda hekimlerin daha etkin şekilde yetiştirilmeleri, mesleksel egoların aşılması, mesleğe gereken özverinin yansıtılması, eğitimde vaka sunumlarının önemsenmesi, klinik dönemin tamamiyla uygulama olması, mezun deneyimlerinden halihazırda öğrenim gören öğrencilerin yararlanmalarının sağlanması, iletişim ve sosyal beceriler konusunda daha iyi yetiştirilmeleri gerektiği mezunların önerileri arasında yer almıştır. Gerek mezunların önerileri gerekse araştırmanın genel sonuçları düşünüldüğünde aşağıdaki öneriler gündeme gelebilir:

- Bilimsel, teknolojik gelişmeye ve toplumsal değişimlere paralel olarak tıp fakülteleri çağdaş sağlık hizmet sunabilen hekimler yetiştirmek için eğitim programlarını ve öğrenim hedeflerini ulusal ve uluslararası standartlar, temel yeterlikler açısından güncellemeli ve eğitimi bu güncellemeye uygun olarak yürütmelidir.

- Mezunların hissettikleri ve mektuplarında dile getirdikleri yetersizliklere dair kuruma, eğitim programına, eğiticilere ilişkin değerlendirmeler/saptamalar fazlaca yer alırken kendilerine ilişkin özeleştiriler ya da verdikleri dönütler nispeten daha azdır. Oysa eğitimin odağında olan öğrencilerin kendisidir. Mezunların kendilerine dair dönüt vermede zayıf kalmaları tıp fakültesi öğrencilerinde; öz farkındalık, mesleki yeterlik algısı, kendi öğrenmeleri üzerine düşünme, bilişsel esneklik, öz yeterlik, öz denetim, öğrenme sorumluluğu alma, öğrenme yaklaşımı, motivasyon, motivasyonel kararlılık, tutum gibi birçok konunun sürekli araştırılmalara konu olması gerekliliğini bir defa daha ortaya koymuştur.

\section{KAYNAKLAR}

1. Patterson F, Ferguson E, Knight AL. Selection into Medical Education and Training. Understanding Medical Education: Evidence, Theory and Practice. Oxford: John Wiley \& Sons, 2014. https://doi.org/10.1002/9781118472361.ch28

2. Bleakley A, Browne J, Ellis K. Quality in Medical Education. Understanding Medical Education: Evidence, Theory and Practice, 2013;47-59.

https://doi.org/10.1002/9781118472361.ch4

3. Laidlaw A, Aiton J, Struthers J, Guild S. Developing Research Skills in Medical Students: AMEE Guide No. 69. Medical Teacher, 2012;34(9): 754-771. https://doi.org/10.3109/0142159X.2012.70443 $\underline{8}$

4. Harasym PH, Tsai TC, Hemmati P. Current Trends in Developing Medical Students' Critical Thinking Abilities. The Kaohsiung Journal of Medical sciences, 2008;24(7): 341355.https://doi.org/10.1016/S1607-

$\underline{551 X(08) 70131-1}$

5. Aper L, Veldhuijzen W, Dornan T, van de Ridder M, Koole S, Derese A, Reniers J. 
"Should I Prioritize Medical Problem Solving or Attentive Listening?": The Dilemmas and Challenges that Medical Students Experience When Learning to Conduct Consultations. Patient Education and Counseling, 2015;98(1): 77-84.

https://doi.org/10.1016/i.pec.2014.09.016

6. Dolmans DHJM, Schmidt H. The Advantages of Problem Based Curricula. Postgraduate Medical Journal, 1996;72: 535538. https://doi.org/10.1136/pgmj.72.851.535

7. Carpenter J. Doctors and Nurses: Stereotypes and Stereotype Change in Interprofessional Education. Journal of Interprofessional Care, 1995;9(2): 151-161. https://doi.org/10.3109/13561829509047849

8. Reinertsen JL. Physicians as Leaders in the Improvement of Health Care Systems. Annals of Internal Medicine, 1998;128(10): 833-838. https://doi.org/10.7326/0003-4819-128-10$\underline{199805150-00007}$

9. Wright EB, Holcombe C, Salmon P. Doctors' Communication of Trust, Care, and Respect in Breast Cancer: Qualitative Study. BMJ, 2004;328(7444): 864-868. https://doi.org/10.1136/bmj.38046.771308.7C

10. Metcalfe D. The Edinburgh Declaration. Family Practice, 1989;6(3): 165-167. https://doi.org/10.1093/fampra/6.3.165

11. World Federation for Medical Education. The Edinburgh Declaration, Lancet, 1988;8068: 464.

12. Açık Y, Oğuzöncül F, Polat A, Güngör Y, Güngör L. Firat Üniversitesi Tıp Fakültesi Öğrencilerinin Tıp Eğitimi ve Mezuniyet Sonrası Hakkındaki Düşünceleri. Toplum ve Hekim, 2002;17: 195-201.
13. Canbaz S, Sünter T, Aker S, Pekşen Y. Tıp Fakültesi Son Sınıf Öğrencilerinin Kaygı Düzeyi ve Etkileyen Faktörler. Genel Tip Dergisi, 2007;17: 15-19.

14. Kılıç B, Sayek İ. Türk Tabipler Birliği Mezuniyet Öncesi T1p Eğitimi Raporu-2000 (TTB-MÖTER). Toplum ve Hekim, 2001;16: 230-240.

15. Yeniçeri N, Mevsim V, Özçakar N, Ozan S, Güldal D, Başak O. Tıp Eğitimi Son Sınıf Öğrencilerinin Gelecek Meslek Yaşamları ile İlgili Yaşadıkları Anksiyete ile Sürekli Anksiyetelerinin Karşılaştırılması. DEÜ Tıp Fakültesi Dergisi, 2007;21: 19-24.

16. Gürpınar E, Musal B. Tıp Eğitiminin Gelişim Süreci. Toplum ve Hekim, 2003;18: 446-451.

17. Sayek İ, Kılıç B. Mezuniyet Öncesi Tıp Eğitimi Raporu-1997. Ankara TTB Yayınları, 1997.

18. Fraenkel JR, Wallen NE. How to Design and Evaluate Research in Education. NY: McGrawHill, 2006.

19. Maxwell JA. Qualitative Research Design: An Interactive Approach. Thousand Oaks, CA: Sage Publications, 1996.

20. Patton MQ. Qualitative Evaluation \& Research Methods. Newbury Park, CA: Sage Publications, 2002.

21. Yıldırım A, Şimşek H. Sosyal Bilimlerde Nitel Araştırma Yöntemleri. Ankara: Seçkin Yayınc1l1k, 2011.

22. Creswell JW. Educational Research: Planning Conducting and Evaluating Quantitative and Qualitative Research. Boston: Pearson Education Inc., 2012. 
23. Marriam SB. Tisdell EJ. Qualitative Research, a Guide to Design and Implementation. The USA: Jossey-Bass, 2016.

24. Shenton AK. Strategies for Ensuring Trustworthiness in Qualitative Research Projects. Education for Information, 2004;22(2): 63-75. https://doi.org/10.3233/EFI2004-22201

25. Christensen LB, Johnson RB, Turner LA. Research Methods, Design, and Analysis. The USA: Pearson, 2014.

26. Creswell JW. Araştırma Deseni: Nitel, Nicel ve Karma Yöntem Yaklaşımları (Çeviri Editörü: Selçuk Beşir Demir). Ankara: Eğiten Kitap, 2014

27. Creswell JW. Qualitative Inquiry \& Research Design, Choosing Among Five Approaches. The USA: Sage Publications Inc., 2007.

28. Mayring P. Qualitative Content Analysis. Forum: Qualitative Social Research (On-Line Journal), 2000;1(2). Retrieved from: http://qualitative-research.net/fqs/fqs-e/2-

$\underline{\text { 00inhalt-e.htm }}$

29. Özmen P, Şahin S, Çetin M, Türk YZ. 2012 Y1lı Gülhane Askeri Tıp Fakültesi Mezunu Tabiplerin Eğitim Algıları ve Gelecek Düşünceleri. Gülhane Tıp Dergisi, 2013;55: 261-268.

https://doi.org/10.5455/gulhane.29251

30. Morrison J, Moffat Glasgow K. More on Medical Student Stress. Medical Education, 2001;35(7): 617-8.

https://doi.org/10.1046/j.1365-

2923.2001.00996.x

31. Whitfield AGW. The Postgraduate's Opinion of His Undergraduate Medical Education. Postgraduate Medical Journal,
1964;40:

313.

https://doi.org/10.1136/pgmj.40.464.313

32. Yarış F, Topbaş M, Çan G. Karadeniz Teknik Üniversitesi Tıp Fakültesi Öğrencilerinin Tip Eğitimi Hakkındaki Düşünceleri. OMU Tıp Dergisi, 2001;18(4): 223-31.

33. Firth J. Levels and Sources of Stress in Medical Students. BMJ, 1986;292(6529): $1177-$ 80. https://doi.org/10.1136/bmj.292.6529.1177

34. Mayda AS, Y1lmaz M, Bolu F, Deler MH, Demir H, Doğru MF, Ekici Eİ, Firat A, Guksu S. Bir Tip Fakültesi 4, 5 ve 6. Sinıf Öğrencilerinde Gelecek ile İlgili Kayg1 Durumunun Değerlendirilmesi. Düzce Üniversitesi Sağlık Bilimleri Enstitüsü Dergisi, 2014;4(3): 7-13.

35. Frank JR, Snell L, Sherbino J. CanMEDS 2015 Physician Competency Framework. Canada: Royal College of Physicians and Surgeons of Canada, 2015.

36. World Federation for Medical Education (WFEME). Task Force on Defining International Standards in Basic Medical Education. Report of a Working Party, Copenhagen 1999. Medical Education, 2000;34(8): 665-675.

https://doi.org/10.1046/j.1365-

2923.2000.00722.x

37. Institute for International Medical Education (IIME). Global Minimum Essential Requirements in Medical Education. MedicalTeacher, 2002;24(2): 130-135. https://doi.org/10.1080/01421590220120731

38. Ulusal Cep-2020 U, Ulusal Cep-2020 U, Ulusal Cep-2020 D. Medical Faculty-National Core Curriculum 2020. Tıp Eğitimi Dünyası, 2020;19(57-1): 1-146. https://doi.org/10.25282/ted.716873 